\title{
TWO NEW SPECIES OF XIPHIDIOCERCARIAE FROM THE THIARID SNAIL PaLUdomus tanschaURICUS IN MALABAR, KERALA
}

\author{
M.V. Vasandakumar ${ }^{1}$ and K.P. Janardanan ${ }^{2}$
}

${ }^{1}$ Department of Zoology, S.N. College, Kannur, Kerala 670007, India; ${ }^{2}$ Department of Zoology, University of Calicut, Kerala 673635, India

\begin{abstract}
Two new species of Xiphidiocercariae larvae, Cercaria III Malabar sp. nov. and Cercaria IV Malabar sp. nov. infecting the thiarid snail, Paludomus tanschauricus, collected from Kanhileri in the Kannur district of Malabar are described and their systematic position discussed.
\end{abstract}

\section{KEYWORDS}

Cercaria, Malabar, new species, sporocyst, snail,

During an expolarative study on the cercarial fauna of freshwater snails in Malabar, we came across two species of Xiphidiocercariae in the thiarid snail, Paludomus tanschauricus collected from Kanhileri in the Malabar region of Kerala. Detailed studies revealed that they are hitherto undescribed species and are, therefore, reported here as new species. The new species are denoted by Roman numerals, followed by Malabar, the region of collection.

\section{Materials ANd Methods}

The thiarid snails, Paludomus tanschauricus, collected from the irrigation canals at Kanhileri (Kannur district), were brought alive to the laboratory and examined for cercariae. The cercariae emerged naturally from the snails were subjected to detailed studies on their morphology and behaviour. Intramolluscan stages were also studied. Measurements were taken from $10 \%$ formalin fixed larvae. Measurements are given in micrometres $(\mu \mathrm{m})$ with mean values in parentheses. Sketches were drawn with the aid of a camera lucida.

\section{Cercaria III Malabar sp. nov.}

(Fig. 1)

The cercariae emerged in small numbers throughout day and night, but in large numbers during afternoon hours. Cercariae swam actively by wriggling movements of body and tail. At rest they remained suspended in the water column. Cercariae exhibited creeping movements at the bottom of the container.

Snail host: Paludomus tanschauricus (Gmelin)

Site of infection: Hepatopancreas

Locality: Kanhileri in Kannur district (Kerala)

Period of collection: June-July 2004.

Prevalence: Five of 200 (2.5\%) snails examined were infected. Type: Smear slide DZUC 17, Department of Zoology, University of Calicut

\section{Description}

(Fig. 1) Virgulate xiphidiocercaria. Body elongate-oval, spinose, 92-149 (122) long, 56-85 (72) wide. Tail spinose, spines larger than body spines; attached postero-ventrally, 56-93 (75) long,
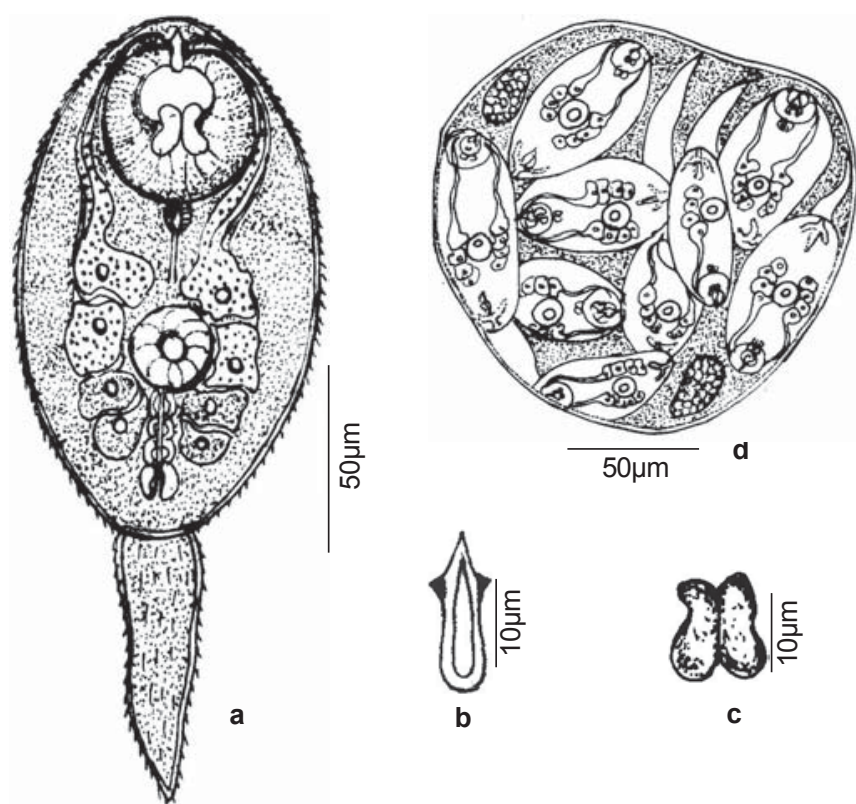

Figure 1. Cercaria III Malabar sp. nov. a - Cercaria; b - Stylet; c - Virgula; $d$ - Sporocyst

13-24 (18) wide. Oral sucker subterminal, large, round, 29-37 (33) in diameter. Stylet prominent, inserted into the roof of oral sucker, 13-14 (13.2) long, 3-3.5 (3.3) wide, stylet walls thick, shoulders moderately developed; virgula organ located at the posterior half of oral sucker; large, bilobed, fused medially, 1324 (17) long and 13-24 (18) wide. Acetabulum post-equatorial, smaller than oral sucker, 16-24 (18) in diameter. Mouth subterminal, ventral. Pharynx well-developed, muscular. Oesophagus short, weakly developed; caeca not traceable. Penetration glands four pairs; anterior pair pre-acetabular, second pair para-acetabular and posterior two pairs postacetabular; contents of anterior two pairs coarsely granular and posterior two pairs finely granular. Ducts of penetration glands open individually near stylet shoulders. Genital primordium consists of a mass of round cells located near posterior margin of acetabulum.

Excretory bladder large, 'I'-shaped, with thick wall lined by cells; excretory pore located dorsally at body tail junction. Flame cell formula $2[(2+2+2)+(2+2+2)]=24$.

\section{Sporocyst}

Sporocysts were recovered from the hepatopancreas of Paludomus tanschauricus. Sporocysts colourless, oval to spherical, saccular, 72-215 (168) long, 69-175 (128) wide, 
Table 1. Comparative characters of cercariae

\begin{tabular}{|c|c|c|c|c|c|c|c|c|}
\hline Species & Body & $\begin{array}{l}\text { Tail } \\
\text { organ }\end{array}$ & $\begin{array}{l}\text { Stylet } \\
\text { glands }\end{array}$ & Virgula & Penetration & $\begin{array}{l}\text { Excretory } \\
\text { bladder }\end{array}$ & $\begin{array}{l}\text { Flame } \\
\text { cells }\end{array}$ & Snail host \\
\hline $\begin{array}{l}\text { Cercaria of } \\
\text { Allossogonoporus } \\
\text { vespertilionis Macy, } 1940\end{array}$ & $\begin{array}{l}142-177 \\
\times 55-67\end{array}$ & $\begin{array}{l}75-105 \\
\times 15-20 \\
\text { aspinose }\end{array}$ & $\begin{array}{l}\text { dorsally prominent, } \\
\text { ventrally diminishing } \\
\text { shoulder }\end{array}$ & $\begin{array}{l}\text { bilobed; } \\
\text { medially folded, } \\
\text { poseriorly free }\end{array}$ & $\begin{array}{l}\text { anterior pairs hyaline, } \\
\text { posterior pairs finely } \\
\text { granular }\end{array}$ & vesicular & 24 & $\begin{array}{l}\text { Fluminicola } \\
\text { virens }\end{array}$ \\
\hline $\begin{array}{l}\text { Cercaria of Pleurogenoides } \\
\text { orientalis (Srivastava,1934) } \\
\text { Yamaguti, } 1958\end{array}$ & $\begin{array}{l}144-152 \\
\times 80-88\end{array}$ & $\begin{array}{l}98-116 \\
\times 20-28 \\
\text { aspinose }\end{array}$ & $\begin{array}{l}\text { pointed nib with collar; } \\
\text { flat base }\end{array}$ & trilobed & $\begin{array}{l}\text { anterior pairs coarsely } \\
\text { granular, posterior pair } \\
\text { finely granular }\end{array}$ & 'U'-shaped & 24 & $\begin{array}{l}\text { Alocinma } \\
\text { travancorica }\end{array}$ \\
\hline $\begin{array}{l}\text { Cercariae indicae } L X I X \\
\text { Murty, } 1976\end{array}$ & $\begin{array}{l}128-168 \\
\times 72-100\end{array}$ & $\begin{array}{l}100-132 \\
\times 24-28 \\
\text { aspinose }\end{array}$ & $\begin{array}{l}\text { pointed tip with thick } \\
\text { collar }\end{array}$ & triangular & all finely granular & 'U'-shaped & 36 & $\begin{array}{l}\text { Amnicola } \\
\text { travancorica }\end{array}$ \\
\hline $\begin{array}{l}\text { Cercaria leyteensis no. } 4 \\
\text { Ito et al., } 1977\end{array}$ & $\begin{array}{l}94-101 \\
\times \quad 49-62\end{array}$ & $\begin{array}{l}59-81 \\
\times 16-23 \\
\text { aspinose }\end{array}$ & $\begin{array}{l}\text { pointed tip,moderate } \\
\text { shoulder }\end{array}$ & flat-shaped & all finely granular & Cup shaped & - & $\begin{array}{l}\text { Oncomelania } \\
\text { quadrasi }\end{array}$ \\
\hline $\begin{array}{l}\text { Cercaria sp. XII Kerala } \\
\text { Mohandas, } 1977\end{array}$ & $\begin{array}{l}138-200 \\
\times 75-100\end{array}$ & $\begin{array}{l}75-97 \\
\times 20-25 \\
\text { spinose }\end{array}$ & $\begin{array}{l}\text { shoulder prominent, } \\
\text { without basal bulb }\end{array}$ & urn-shaped & all coarsely granular & 'V'-shaped & 20 & $\begin{array}{l}\text { Diagnostoma } \\
\text { pulchella }\end{array}$ \\
\hline $\begin{array}{l}\text { Cercaria microvirgula } \\
\text { Haseeb and Khan, } 1987\end{array}$ & $\begin{array}{r}109-143 \\
\times 57-71\end{array}$ & $\begin{array}{l}71-129 \\
\times 18-23 \\
\text { spinose }\end{array}$ & $\begin{array}{l}\text { fine tip, prominent } \\
\text { shoulder, round base }\end{array}$ & reniform & all coarsely granular & 'V'-shaped & 10 & $\begin{array}{l}\text { Lymnaea } \\
\text { rufescens }\end{array}$ \\
\hline $\begin{array}{l}\text { Cercaria of Mehraorchis } \\
\text { ranarum Srivastava, } 1934\end{array}$ & $\begin{array}{r}144-152 \\
\times 86-92\end{array}$ & $\begin{array}{l}96-100 \\
\times 20-22 \\
\text { aspinose }\end{array}$ & $\begin{array}{l}\text { nib with lateral } \\
\text { projections }\end{array}$ & $\begin{array}{l}\text { bilobed, inverted } \\
\text { 'V'-shaped }\end{array}$ & $\begin{array}{l}\text { anterior pairs coarsely } \\
\text { granular, posterior pairs } \\
\text { finely granular }\end{array}$ & 'V'-shaped & 24 & $\begin{array}{l}\text { Alocinma } \\
\text { travancorica }\end{array}$ \\
\hline $\begin{array}{l}\text { Cercaria of Peurogenoides } \\
\text { ovatus Rao, } 1977\end{array}$ & $\begin{array}{l}96-122 \\
\times 66-84\end{array}$ & $\begin{array}{l}45-74 \\
\times 18-24 \\
\text { aspinose }\end{array}$ & $\begin{array}{l}\text { pointed nib moderate } \\
\text { shoulder,round base, } \\
\text { walls reinforced } \\
\text { except at base }\end{array}$ & $\begin{array}{l}\text { bilobed each lobe } \\
\text { retort shape }\end{array}$ & $\begin{array}{l}\text { Anterior pair finely } \\
\text { granular, remaining } \\
\text { pairs coarsely granular }\end{array}$ & 'V'-shaped & 24 & $\begin{array}{l}\text { Digoniostoma } \\
\text { pulchella }\end{array}$ \\
\hline $\begin{array}{l}\text { Cercaria III Malabar } \\
\text { sp. nov. }\end{array}$ & $\begin{array}{l}92-149 \\
\times 56-85\end{array}$ & $\begin{array}{l}56-93 \\
\times 13-24 \\
\text { spinose }\end{array}$ & $\begin{array}{l}\text { thick walled, } \\
\text { moderately } \\
\text { developed shoulder }\end{array}$ & $\begin{array}{l}\text { bilobed, fused } \\
\text { medially }\end{array}$ & $\begin{array}{l}\text { anterior pairs coarsely } \\
\text { granular, posterior pairs } \\
\text { finely granular }\end{array}$ & 'l'-shaped & 24 & $\begin{array}{l}\text { Paludomus } \\
\text { tanschauricus }\end{array}$ \\
\hline
\end{tabular}

containing 7-14 developing cercariae and a few germ balls at various stages of development.

\section{Remarks}

Of the known virgulate Xiphidiocercariae with spinose body and four pairs of penetration glands, the present form comes close to cercaria of Allossogonoporus vespertilionis Macy, 1940 (Burns, 1961), cercaria of Pleurogenoides orientalis (Srivastava, 1934; Yamaguti, 1958; Murty, 1976; Madhavi et al., 1987), Cercariae indicae LXIX Murty, 1976, Cercaria leyteensis no. 4 Ito et al., 1977, Cercaria sp. XII Kerala Mohandas, 1977, Cercaria microvirgula Haseeb and Khan, 1987, cercaria of Mehraorchis ranarum Srivastava, 1934 (Ratnakumari et al., 1991) and that of Pleurogenoides ovatus Rao, 1977 (Janardanan \& Prasadan, 1991).

Comparative characters of the cercariae presented in Table 1 shows that cercaria of $A$. vespertilionis differs from the present form in the shape of stylet and virgula organ, nature of penetration gland contents and in having aspinose tail. Cercariae of $P$. orientalis, $M$. ranarum and $P$. ovatus, Cercariae indicae LXIX, Cercaria leyteensis no.4, Cercaria sp. XII Kerala and $C$. microvirgula have oval or ' $\mathrm{V}$ '-shaped excretory bladder, whereas that of the present form is 'I'-shaped. Cercaria of $P$. orientalis, C. leyteensis no. 4, Cercaria sp. XII Kerala and C. microvirgula further differ from the present cercaria in the nature of penetration gland contents. In the shape of stylet and virgula organ also $C$. indicae LXIX and cercariae of M. ranarum and $P$. ovatus differ from the present cercaria. Besides, the snail host of the present form is different from that of above cercariae. Hence it appears reasonable to consider the present cercaria as new and the name Cercaria III Malabar sp. nov. is proposed for it.

\section{Cercaria IV Malabar sp. nov.} (Fig. 2)

The cercariae emerged throughout day time, but peak emergence was noticed during afternoon hours. Newly emerged cercariae swam for a short period by vigorous lashing activity of tail, then sank to the bottom of the container and encysted there.

Snail host: Paludomus tanschauricus (Gmelin)

Site of infection: Hepatopancreas

Locality: Kanhileri in Kannur district (Kerala)

Period of collection: June-July 2004

Prevalence: Three of 200 (1.5\%) snails examined were infected Type: Smear slide DZUC 18, Department of Zoology, University of Calicut

\section{Description}

(Fig. 2) Non-virgulate xiphidiocercaria. Body elongate-oval, spinose, 85-170 (109) long, 49-66 (57) wide. Tail shorter than body, spinose, highly contractile, attached postero-ventrally; 59-80 (72) long, 9-17 (13) wide. Oral sucker round, 19-33 (27) in 


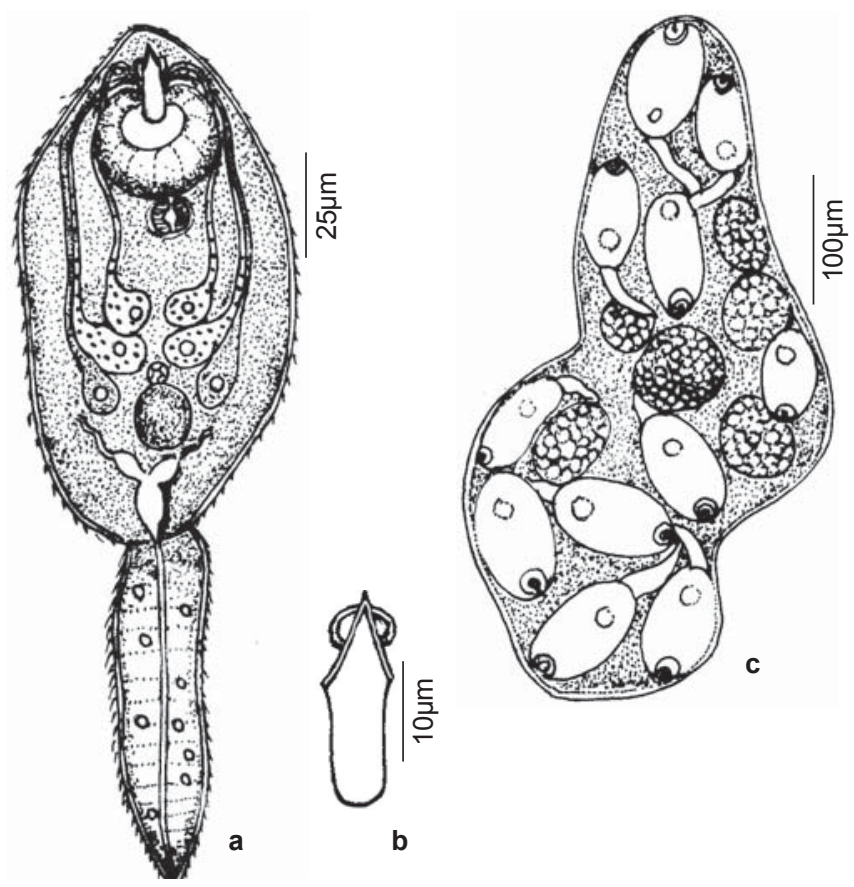

Figure 2. Cercaria IV Malabar sp. nov. a - Cercaria; b - Stylet; c - Sporocyst

diameter. Stylet prominent, inserted into the roof of oral sucker, spear-shaped with fine tip, round base and prominent shoulders at its anterior one-third; 18-20 (19.6) long, and 3.3-4.1 (3.5) thick at shoulder region. Acetabulum rudimentary, located in posterior half of body.

Mouth ventral, subterminal. Pharynx well-developed, muscular, 6-10 (8) in diameter. Penetration glands three pairs; anterior two pairs pre-acetabular and posterior pair para-acetabular with their ducts opening near stylet shoulders. Glands round to oval with fairly large nuclei. Contents of anterior two pairs coarsely granular and posterior pair finely granular.
Cystogenous glands numerous, filled with refringent granules, distributed all over the body. Genital primordium represented by a round mass of cells situated anterior to acetabular rudiment.

Excretory bladder ' $\mathrm{Y}$ '-shaped with a round base and two broad cornuae; each cornua gives rise to an ascending main excretory duct which takes a convoluted course upto the level of acetabulum and divides into anterior and posterior collecting tubules. Flame cell formula $2[(2+2)+(2+2)]=16$. Excretory pore situated at body-tail junction. Caudal excretory canal extend to the tip of tail.

\section{Sporocyst}

Sporocysts were recovered from the hepatopancreas of Paludomus tanschauricus. Sporocysts oval to elongate, saclike, 346-577 (473) long, 154-285 (205) wide; enclose 6 to 17 developing cercariae and a few germ balls at various stages of development.

\section{Remarks}

Distome non-virgulate xiphidiocercariae with three pairs of medially placed penetration glands and poorly developed acetabulum showing close resemblance to the present cercaria are Cercariae indicae LII Sewell, 1922, Cercaria leyteensis no. 5 Ito et al., 1977, C. leyteensis no.27 Ito, 1977 and C. visakhapatnamensis 5 Dhanumkumari et al., 1990. A comparison of characters of the present cercaria is given in Table 2. The present form differs from all these cercariae in one or more of the following characters: body size, stylet shape and size, position and shape of penetration glands and the nature of their contents, number of flame cells, shape of excretory bladder and presence or absence of spines on tail. C. indicae LII is distinctly different from the present cercaria in shape and size of stylet, arrangement of penetration glands and nature of their contents, shape of excretory bladder and in having aspinose tail with a cap of spines at its tip. C. leyteensis no.5 has stylet with indistinct shoulders, well developed oesophagus, four pairs of sensory hairs on the body and ' $U$ '-

Table 2. Comparative characters of cercariae

\begin{tabular}{|c|c|c|c|c|c|c|c|}
\hline Species & Body & Tail & $\begin{array}{l}\text { Stylet } \\
\text { glands }\end{array}$ & $\begin{array}{l}\text { Penetration } \\
\text { bladder }\end{array}$ & $\begin{array}{l}\text { Excretory } \\
\text { cells }\end{array}$ & Flame & Snail host(s) \\
\hline $\begin{array}{l}\text { Cercariae indicae LII } \\
\text { Sewell, } 1922\end{array}$ & $\begin{array}{l}82-89 \times 21-25 \\
\text { spinosewithout } \\
\text { sensory hairs }\end{array}$ & $\begin{array}{l}82-89 x ? \text { aspinose } \\
\text { with cap of spines } \\
\text { at tip }\end{array}$ & $\begin{array}{l}\text { narrow elongate } \\
\text { with thick } \\
\text { shoulder }\end{array}$ & $\begin{array}{l}\text { outer pair coarsely } \\
\text { granular, other pairs } \\
\text { finely granular }\end{array}$ & spherical & - & $\begin{array}{l}\text { Amnicola } \\
\text { travanorica }\end{array}$ \\
\hline $\begin{array}{l}\text { Cercaria leyteensis } \\
\text { no. } 5 \text { Ito et al., } 1977\end{array}$ & $\begin{array}{l}70-8332-35 \\
\text { spinose with } 4 \text { pairs } \\
\text { of sensory hairs }\end{array}$ & $\begin{array}{l}50-58 \times 15-20 \\
\text { spinose } \\
\text { bent ventrally }\end{array}$ & $\begin{array}{l}\text { solid, pointed with } \\
\text { indistinct shoulder; }\end{array}$ & all coarsely granular & 'U'-shaped & - & $\begin{array}{l}\text { Oncomelania } \\
\text { quadrasi }\end{array}$ \\
\hline $\begin{array}{l}\text { Cercaria leyteensis } \\
\text { no. } 27 \text { Ito et al., } 1977\end{array}$ & $\begin{array}{l}70-95 \times 30-40 \\
\text { spinose without } \\
\text { sensory hairs }\end{array}$ & $\begin{array}{l}60-80 \times 10-15 \\
\text { aspinose }\end{array}$ & $\begin{array}{l}\text { sharply pointed } \\
\text { with conspicuous } \\
\text { shoulders }\end{array}$ & $\begin{array}{l}\text { anterior pairs finely } \\
\text { granular, posterior pair } \\
\text { coarsely granular }\end{array}$ & 'V'-shaped & 16 & $\begin{array}{l}\text { Pila ampullacea, } \\
\text { P. luzonica, } \\
\text { Bellamya } \\
\text { philippinensis }\end{array}$ \\
\hline $\begin{array}{l}\text { Cercaria } \\
\text { visakhapatnamensis } \\
5 \text { Dhanumkumari } \\
\text { et al., } 1990\end{array}$ & $\begin{array}{l}112-126 \times 78-90 \\
\text { spinose without } \\
\text { sensorty haris }\end{array}$ & $\begin{array}{l}72-81 \times 15-21 \\
\text { aspinose }\end{array}$ & $\begin{array}{l}\text { solid with thick } \\
\text { shoulder, broad } \\
\text { base }\end{array}$ & $\begin{array}{l}\text { anterior pairs finely } \\
\text { granular, posterior pair } \\
\text { coarsely granular }\end{array}$ & 'V'-shaped & - & $\begin{array}{l}\text { Thiara } \\
\text { tuberculata }\end{array}$ \\
\hline $\begin{array}{l}\text { Cercaria IV Malabar } \\
\text { sp. nov. }\end{array}$ & $\begin{array}{l}85-170 \times 49-66 \\
\text { spinose without } \\
\text { sensoryhairs }\end{array}$ & $\begin{array}{l}59-80 \times 9-17 \\
\text { spinose }\end{array}$ & $\begin{array}{l}\text { spear shaped with } \\
\text { fine tip, prominent } \\
\text { shoulder, round base }\end{array}$ & $\begin{array}{l}\text { anterior pairs coarsely } \\
\text { granular, posterior pair } \\
\text { finely granular }\end{array}$ & 'Y'- shaped & 16 & $\begin{array}{l}\text { Paludomus } \\
\text { tanschauricus }\end{array}$ \\
\hline
\end{tabular}


shaped excretory bladder. These characters make $C$. leyteensis no. 5 different from the present form. C. leyteensis no. 27 and $C$. visakhapatnamensis 5 also differ from the present cercaria in having aspinose tails, fine granular secretion in anterior two pairs of penetration glands and coarse granular secretion in posterior pair. Further, the snail hosts of the above mentioned cercariae are also different. As the present cercaria cannot be identified with any other known cercaria, it is considered as new and the name Cercaria IV Malabar sp. nov. is proposed for it.

\section{REFERENCES}

Burns, W.C. (1961). Six virgulate xiphidiocercariae from Oregon, including redescription of Allossogonoporus vespertilionis and Acanthatrium oregonense. Journal of Parasitology 47(6): 919-925.

Janardanan, K.P. and P.K. Prasadan (1991). Studies on the lifecycle of Pleurogenoides ovatus Rao, 1977 (Trematoda: Pleurogenetinae). Journal of Helminthology 65: 43-50.

Madhavai, R., C. Dhanumkumari and T.B. Retnakumari (1987). The life history of Pleurogenoides orientalis (Srivastava,1934) (Trematoda: Lecithodendriidae). Parasitology Research 73: 41-45.

Murty, A.S. (1976). Studies on Indian cercariae III. Virgulate Plagiorchioid cercariae. Proceedings of the Indian Academy of Science 83(1): 12-17.

Retnakumari, T.B., R. Madhavi and C. Dhanumkumari (1991). The life cycle of Mehraorchis ranarum Srivastava, 1934 (Trematoda, Lecithodendriidae). Acta Parasitologica Polonica 36(1): 5-10.

\section{ACKNOWLEDGEMENTS}

One of the authors (M.V.V.) is grateful to the University Grants Commission for providing financial assistance in the form of Minor Research Project (MRP(S)186/2004).

\section{ADDITIONS TO THE MAMMALIAN AND AVIAN DIVERSITY OF NALLAMALA HILLS, WITH TWO NEW MAMMAL RECORDS}

\section{Srinivasulu}

Wildlife Biology Section, Department of Zoology, Osmania University, Hyderabad, Andhra Pradesh 500007, India Email: hyd2_masawa@sancharnet.in

Srinivasulu \& Nagulu (2002) catalogued the mammalian and avian diversity of the Nallamala Hills, Andhra Pradesh and reported the presence of 74 species of mammals and 302 species of birds based on literature and faunistic surveys conducted by the present author from 1996 to 2000 . Since then, further surveys conducted by the author and others have resulted in addition to hitherto unknown mammals and birds. Recent taxonomic revision in colobines of South Asia warrants recognition of two different species of langurs in the region (Brandon-Jones, 2004). This note adds six mammals and one bird species to the known diversity of the mammals and birds increasing the diversity to 80 species and 303 species, respectively, with two new mammalian records for the Nallamala Hills. Brief notes on the new species are provided below.

\section{Mammals}

Of the mammalian diversity reported by Srinivasulu \& Nagulu (2002) one species, namely, the Common (Hanuman) Langur Semnopithecus entellus is now represented by two species in the Nallamala Hills. Further comments are provided against the new species of langur below. The details of the six mammalian species are provided below.

1. Eonycteris spelaea Dawn Bat (Chiroptera: Pteropodidae) One female specimen mist netted and collected from the forested tracts near Potharajupenta, Kurnool district on 23 May 1995 (Chakraborty et al., 2004; Ghosh, pers. comm.) puts on record its presence from Nallamala Hills, Eastern Ghats. Until now the Dawn Bat was known only from Vishakapatnam district, Andhra Pradesh (Bates \& Harrison, 1997; Srinivasulu \& Srinivasulu, 2004). This constitutes its range extension from northern Eastern Ghats in the Ananthagiri Hills to the central Nallamala Hills in Kurnool district.

2. Rhinolophus lepidus Blyth's Horseshoe Bat (Chiroptera: Rhinolophidae) - A total of 14 specimens were collected from Akkamahadevi Bilam Cave, Mahbubnagar district on two occasions - 26 March 2002 and 9 June 2003. This species had been earlier collected from Cuddapah, Vishakapatnam and East Godavari districts from the state (Bates \& Harrison, 1997; Chakraborty et al., 2004; Srinivasulu \& Srinivasulu, 2004). This constitutes the first record of Rhinolopus lepidus in the Nallamala Hills, Eastern Ghats. 